\title{
MAŽOS TREPANACIJOS (MINITREPANACIJOS) METODIKA ŠALINANT GALVOS SMEGENŲ HEMORAGINI INSULTĄ. KLINIKINIS ATVEJIS IR METODIKOS APRAŠYMAS
}

\author{
Dmitrij Aleksandrov \\ Klaipèdos universitetinès ligoninès Neurochirurgijos klinika
}

Raktažodžiai: intracerebrinis kraujavimas, intracerebrinių hematomų patofiziologija, intracerebrinių hematomų šalinimo metodai, mažos trepanacijos (minitrepanacijos) metodas.

\begin{abstract}
Santrauka
Šiame straipsnyje apžvelgiama intracerebrinių hematomų chirurginiai gydymo metodai, jų privalumai ir trūkumai. Taip pat pateikiamas klinikinis atvejis ir metodinè intracerebrinių hematomų šalinimo rekomendacija, naudojant naują metodą - mažos trepanacijos (minitrepanacijos) metodą.
\end{abstract}

\section{Ivadas}

Intracerebralinis kraujavimas (ICH) yra dažna liga, kurios sergamumas svyruoja nuo 11 iki 35 atvejų per 100.000 per metus. Nors tai sudaro nuo 10 iki $15 \%$ visų insultų, intracerebrinis kraujavimas yra labiausiai paplitęs insulto potipis. Mirtingumas siekia iki 40\% [1-4]. Kiti tyrimai nurodo, kad mirtingumas per 30 dienų nuo ICH siekia $35-52 \%$ pacientų ir tik $20 \%$ pacientų būna funkciškai nepriklausomi po 6 mènesių [5]. Po vienerių metų miršta arba būna itin sunkios būklès net $75 \%$ pacientų ir tik maža dalis išgyvenusių lieka visiškai funkciškai nepriklausomi [6].

Pasaulinė statistika byloja, jog per metus maždaug 15 milijonų žmonių Žemèje patiria insultą. Kone $6 \mathrm{mln}$. iš jų dèl to miršta. Europos Sajungoje (ES) pastaraisiais metais kasmet insultą patiria 1,1 mln. gyventojų. Gydymo kaštai per metus, susiję su insulto gydymu bei kitais faktoriais prarastu darbingumu, slauga, vaistų kompensavimu - ES siekia per 65 milijardus eurų.

Intrakranijinès kraujosruvos (ICH) gali būti klasifikuojamos pagal anatominius ar etiologinius aspektus. Pagal anatominius aspektus kraujosruvos klasifikuojamos i : parenchiminius (ICH/IPH), subarachnoidinius (SAH), subduralinius $(\mathrm{SDH})$, epiduralinius $(\mathrm{EDH})$, intraventrikulinius (IVH). Galimas ir kitas kraujosruvų klasifikavimas pagal lokalizaciją į: 1) subtentorinès (smegenèlių, tilto) bei 2) supratentorinès: giliosios (thalamus, N.caudatus, putamen), vidinès kapsulès atžvilgiu - medialinès/ lateralinès, ir paviršinès (skiltinès arba subkortikalinės) [7].

Pagal etiologinius aspektus intracerebrinès kraujosruvos klasifikuojamos ị pirmines ir antrines. Pirminè (spontaninè) dažniausiai atsiranda dẻl smulkiujų kraujagyslių plyšimo ir yra susijusi su hipertenzija, antikoaguliantų vartojimu, amiloidine angiopatija. Tuo tarpu antrinè intracerebrinè kraujosruva (sudaro $12-20 \%$ visų ICH) būna dèl kitų kraujagysliu plyšimo (pvz., aneurizmos, AVM) [8,9].

Šiame straipsnyje pateikiamas hemoraginio insulto šalinimo metodas (klinikinis atvejis), naudojant mažos trepanacijos (minitrepanacijos) metodiką bei metodinè rekomendacija.

\section{Ligos patofiziologija}

Intracerebrinè kraujosruva - tai dinaminis procesas, kuris susideda iš kelių etapų: pirmas etapas, pradinis pakraujavimas. Dél ūmaus kraujavimo atsiranda grubi mechaniné smegenų audinio destrukcija bei didejja intrakranijinis slègis. Intrakranijinis slègis dideja tol, kol hematomos viduje slègis susilygins su arteriniu. Tuo metu dažniausiai ịvyksta 2 etapas: kraujosruvos didejimas. Hematomos didejjimas ir pakartotinis kraujavimas dažniausiai pasireiškia praejjus 4 val. po hemoraginio insulto pasireiškimo pradžios [10]. Dèl hematomos didejjimo atsiranda galvos smegenų anatominių struktūrų dislokacijos, tokiu būdu suspaudžiamos normaliosios kraujagyslès ir vystosi galvos smegenų išemija. Po to būna 3 etapas: aplink kraujosruvą esančios edemos atsiradimas bei vẻliau sekančios fiziologinès ir biocheminès reakcijos. Dèl atsiradusios edemos būna antrinis smegenu pažeidimas, pasireiškiantis ryškiu neurologinès būklès pablogèjimu [7,11].

Ligos eigą dažniausiai lemia dvi paskutinès fazès. Ankstyvas neurologinès funkcijos sutrikimas atsiranda dèl kraujosruvos didèjimo, o mirtingumas eksponentiškai didejja, kai hematomos tūris viršija $30 \mathrm{ml}$ [12].

Net iki $45 \%$ intraceberinių kraujosruvų prasiveržia ị 
skilvelių sistemą[13]. Pastebèta tiesioginè koreliacija tarp prasiveržusio kraujo tūrio ir blogų ligos baigčių [14]. Atliktuose tyrimuose nustatyta, kad intracerebrinis pakraujavimas, kuris komplikavosi dèl intraventrikulinio pakraujavimo, padidina mirtingumą net $80 \%$ [14-16].

Pablogèjusią ligos eigą dèl intraventrikulinès hemoragijos ar kraujo prasiveržimo ị skilvelių sistemą sąlygoja keturi pagrindiniai veiksniai: 1) ūmi obstrukcinè hidrocefalija;
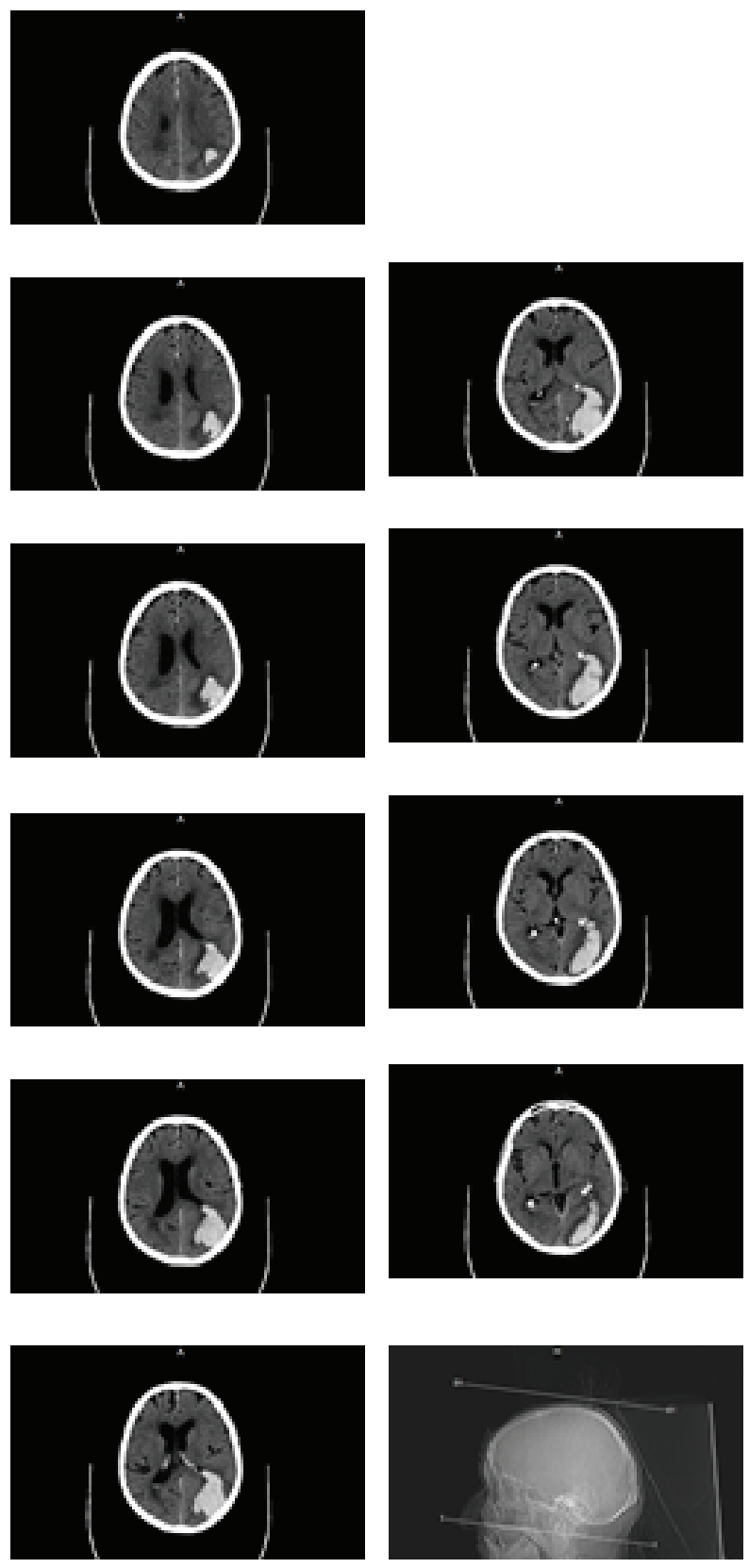

1 pav.
2) atsiradęs masès efektas; 3) kraujo irimo produktų toksiškumas smegenų parenchimai; 4) lètinès susisiekiančios hidrocefalijos išsivystymas (dèl arachnoidinių granuliacijų randejjimo) [17].

\section{Klinikinio atvejo aprašymas}

Ligonis K.A., 83 metų amžiaus, susirgo 2016.03.21 ryte, kai aukšto kraujospūdžio fone pajuto stiprų skausmą galvoje ir prarado sąmonę. Atgavus sąmonę, išryškejjo kairès puses hemiparezè iki 3 balų, regèjimo sutrikimai, grubi motorinè disfazija. Anamnezè sunki, nes ligonis buvo gydomas dèl širdies nepakankamumo, turèjo mažą išmetimo
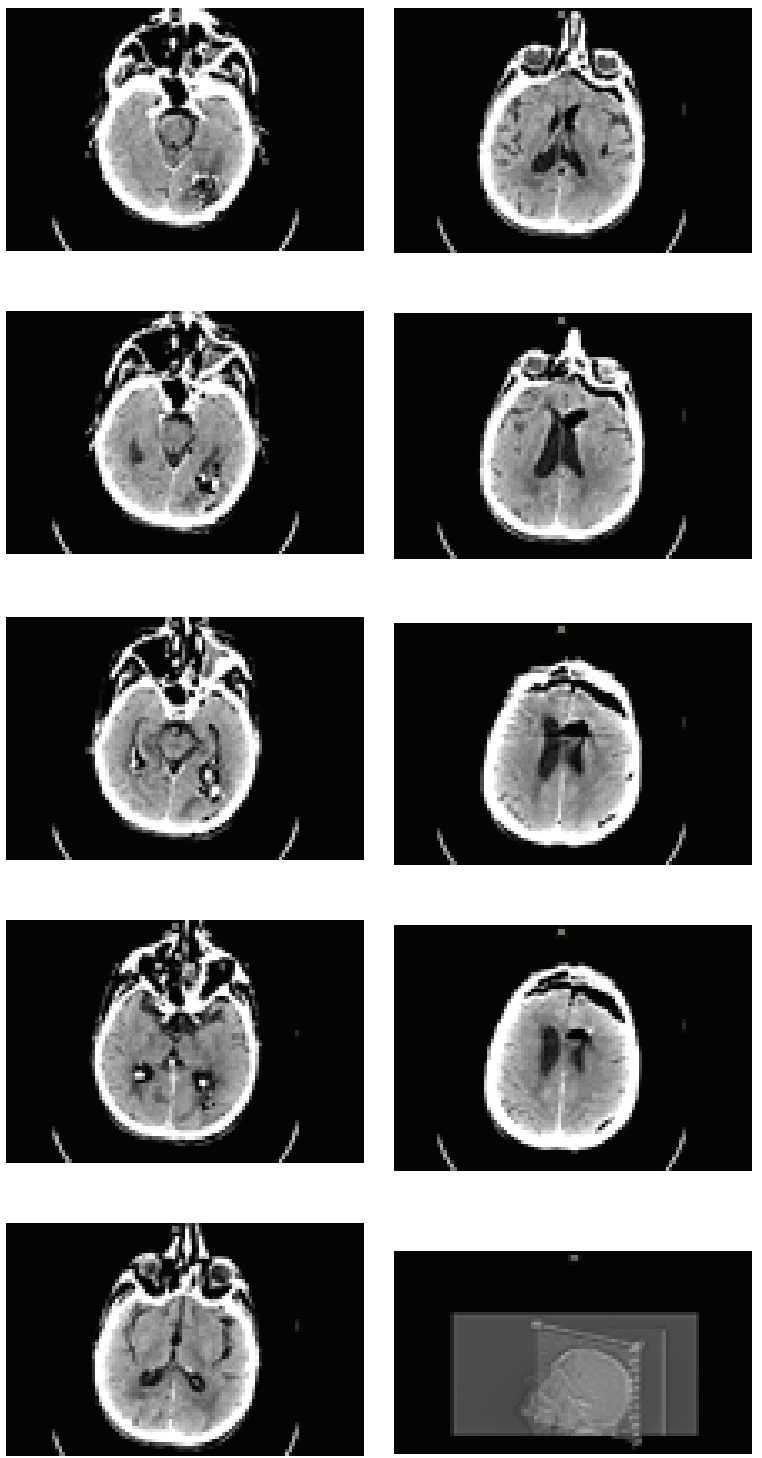

2 pav. 
frakciją bei vartojo orfariną. Prieš tai ligonis karščiavo iki $38^{\circ} \mathrm{C}$. Dèl minètų nusiskundimų buvo iškviesta GMP, kuri pristate ligoni i KUL LPS. Atlikus KT: kaireje momenineje ir kaireje pakaušinejje skiltyse stebèta apie $70 \mathrm{~cm}^{3}$ intracerebrinè hematoma, sukelianti vidurinių linijų darinių dislokaciją (1 pav.). Atlikus plaučių rentgenogramą nustatytas plaučių uždegimas. Ligonis GKS - 11b stacionarizuotas RITS. Ligonis dèl blogejjančios būklès iki GKS-8b skubos tvarka buvo operuojamas pagal minitrepanacijos metodiką. Operacijos metu buvo visiškai pašalintas kraujo krešulys, operacijos trukmè nuo pjūvio iki tvarsliavos uždejjimo 42 minutès. Ligonis po operacijos sugrąžintas į RITS. Po 6 valandų buvo atlikta kontrolinè galvos smegenų KT, kurioje matyti, kad hematoma radikaliai pašalinta, vidurinių linijų darinių dislokacija atsistate (2 pav.). Po operacijos galima stebèti, kad dešinės pusės hemiparezė pilnai regresavo, išliko nežymūs regèjimo sutrikimai bei dalinè motorinè disfazija. Po 19 dienų pagydžius užleistą plaučių uždegimą, ligonis išrašomas tolimesniam reabilitaciniam gydymui. Išrašymo

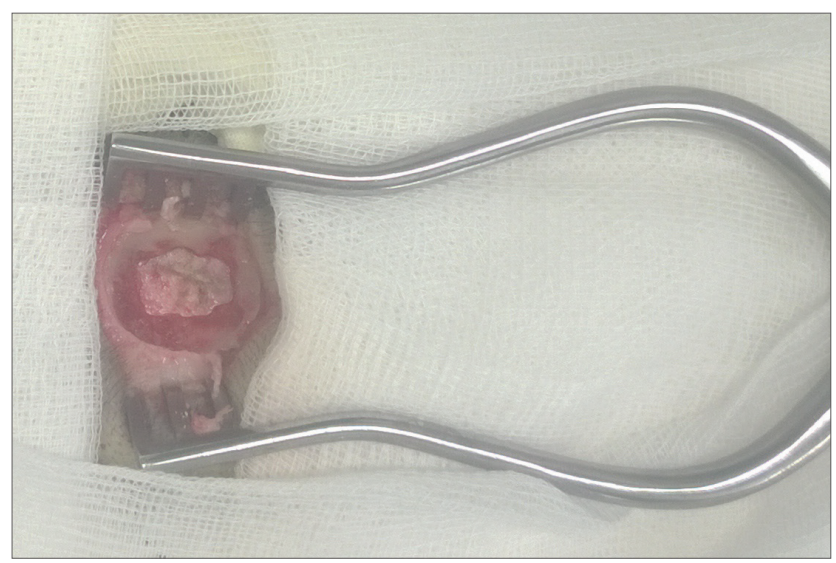

3 pav.

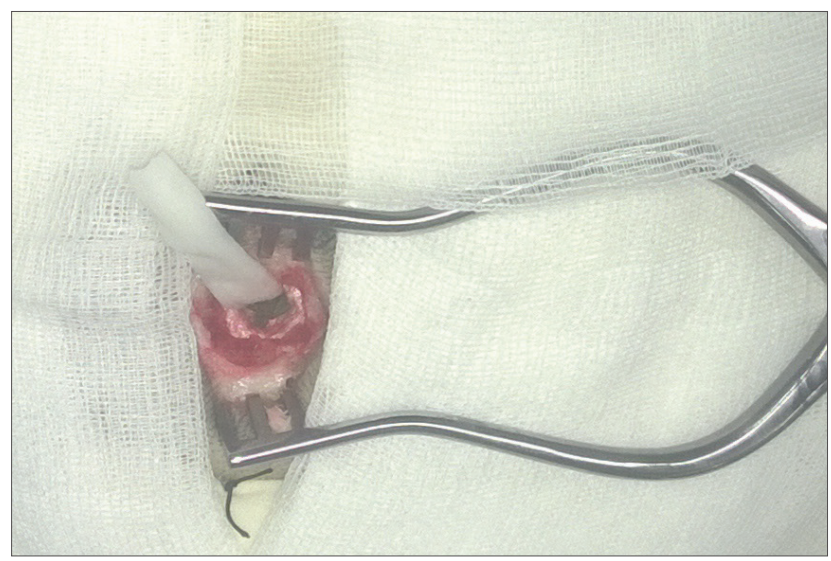

4 pav. metu buvo nustatyta pilnutinai regresavusi hemiparezè bei regresavusi motorinè disfazija, išliko nežymūs regejjimo sutrikimai. Po 2 ménesių atvykus planinei konsultacijai stebima, kad buvusi neurologinè simptomatika regresavo, išliko nežymūs regejjimo sutrikimai.

Mažos trepanacijos (minitrepanacijos) metodo esmė. Hematomos vietoje atliekamas linijinis apie $4-5 \mathrm{~cm}$ linijinis pjūvis. Po to atliekama apie 2-3 cm dydžio kraniotomija (3 pav.). Kietasis smegenų dangalas atveriamas kryžminiu būdu. Atliekama apie 1-1,5 cm kortikotomija. Kraujosruvos šalinimo trajektorija turi būti tokia, kad hematomą galima būtų pasiekti per trumpiausią kelią, išvengiant tolimesnių svarbių struktūrų sužalojimų. Panaudojant mano (Aleksandrov) tam specialiai sukurtą instrumentą, smegenų žievès laikiklį, prieiname prie kraujosruvos. Po to siurblio pagalba pašalinama kraujosruva. Smegenų žievè prilaikoma špateliais arba smegenų audinių laikikliu, atliekama hemostazè kaustika, po to išklojama ertmè hemostatine medžiaga (surgesel). Isitikinus, kad hemostazè gera, susiuvamas kietasis dangalas, sugrąžinamos kaulų drožlès, susiuvami pasluoksniui audiniai $(4,5$ pav.).

\section{Aptarimas}

Intracerebrinès kraujosruvos chirurginis gydymas. Diskusijos, ar reikia intracerebrines kraujosruvas šalinti chirurginiu būdu ar taikyti medikamentini gydymą vyksta daugiau nei 100 metú.

Atlikti tyrimai yra labai prieštaringi. Vis dèlto iš atliktų tyrimų neišaiškintas ryškaus chirurginio gydymo pranašumas. Antai tyrimas, kuri atliko Mendelov ir kiti, parodè, kad

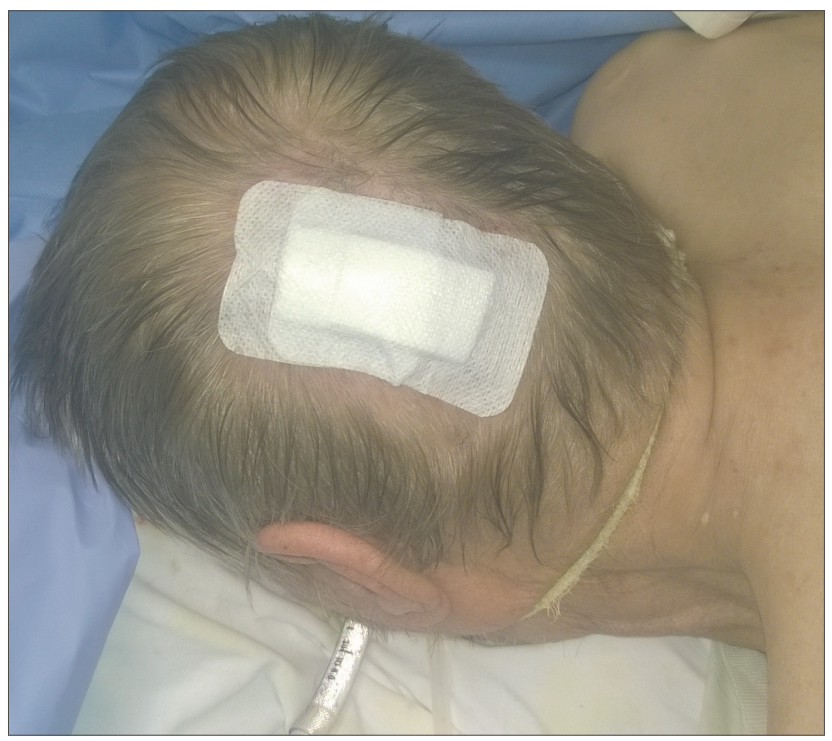

5 pav. 
nėra jokių reikšmingų skirtumų tarp chirurginių ir nechirurginių gydymo grupių. Geras rezultatas buvo stebimas $26 \%$ chirurginio ir $24 \%$ medikamentinio gydymo grupeje. Net mirtingumo rodikliai po 6 ménesių buvo beveik identiški: $36 \%$, lyginant su $37 \%$ atitinkamai. Be to, tyrimas parode, kad prastas pradinis GCS (mažiau nei 9) yra susijęs su prastais gydymo rezultatais nepriklausomai nuo to, ar ligonis buvo operuotas, ar ne [4].

Nors ir šis tyrimas turèjo nemažai trūkumų, kurie galèjo tureti ịtaką rezultatams, tad diskusijos ir aptarimai vyksta iki šiol.

Visgi yra vienas veiksnys, kuris sustiprina indikacijas operacijai: ankstyvas hematomos augimas sukelia tolesni ligonio neurologinị pablogèjimą, atsirandantị trečdaliui pacientų, kuriems yra ICH [18]. Hematomos pašalinimas gali būti naudingas, nes jis sumažina neurotoksinę edemą, kurią sukelia didelis trombino kiekis[19] ir kraujo degradacijos produktai [20].

Manoma, jog intracerebrinès kraujosruvos evakuacija gali lemti neurologinès būklès pagerejjimą ir pagerinti ligos eigą dẻl šių priežasčių: 1) sumažinamas kraujosruvos sukeliamas masès efektas, kuris gali lemti mirtinas komplikacijas (pvz., smegenų kamieno kompresiją); 2) sumažinamas intrakranijinis spaudimas, dèl to gerejja smegenų perfuzija ir veninis drenažas; 3) sumažinama aplink kraujosruvą esanti edema, todèl mažèja antrinio smegenų pažeidimo tikimybė; 4) pašalinami iš ekstravazavusio kraujo išsiskyrę toksiški ir vazoaktyvūs junginiai, kurie taip pat gali sukelti antrinị smegenų pažeidimą [21].

Paskelbtus metaanalizès duomenis, minimaliai invazinę chirurgiją (endoskopinis arba stereotaksinis hematomos šalinimas) geriausia taikyti, kai ICK tūris yra tarp 25 ir 40 $\mathrm{ml}$. Tokiu atveju stebimas didžiausias šio gydymo metodo efektyvumas [22]. Tuo tarpu didesnę kraujosruvą dažniausiai siūloma šalinti atviruoju būdu, o mažesnes dažnai galima palikti ir konservatyviam gydymui.

Optimalus laikas, kada reikia atlikti šią procedūrą vis dar išlieka diskusijų objektu. Vieningai sutariama, kad intervenciją būtina atlikti kuo skubiau nuo hemoraginio insulto pasireiškimo pradžios. Taip bent iš dalies pašalinamas neurotoksinis kraujo irimo produktų poveikis. Antra vertus, pernelyg ankstyva ICK aspiracija gali būti pavojinga dèl didelès pakartotinio kraujavimo rizikos [23]. Hematomos didejjimas ir pakartotinis kraujavimas dažniausiai pasireiškia praejus 4 val. po hemoraginio insulto pasireiškimo pradžios [10]. Dèl šių priežasčių siūloma hematomos pašalinimą atlikti praejjus mažiausiai 6 val., bet ne daugiau nei 72 val. nuo simptomų pasireiškimo pradžios [22].

Šiuo metu neurochirurgų praktikoje įsitvirtinusios trys metodikos, šalinant intracerebrines hematomas: atvira kra- niotomija ir hematomos šalinimas, endoskopinis hematomos šalinimas bei stereotaksinis hematomos šalinimas su vietine fibrinolize.

1. Atvira kraniotomija ir hematomos šalinimas. Pagrindinè metodo esmè: atliekama pakankamai didelè kraniotomija, kad būtų patogu operuoti toje vietoje, kur hematoma pasiekiama per trumpiausią kelią, išvengiant tolimesnio svarbių struktūrų sužalojimo. Atliekama kortikotomija (pagal galimybes kuo mažesnè), sustabdžius kraujavimą prieinama bei matomumo ribose pašalinama kraujosruva (žnyplèmis ir/ ar siurbliu). Po to atliekama hemostazè pagal atskirų klinikų metodikas. Priklausomai nuo klinikų tradicijų bei metodikų naudojamas arba nenaudojamas mikroskopas. Tačiau įrodyta, kad naudojant mikroskopą geriau atliekama hemostazè bei pasiekiamas pilnesnis hematomos šalinimas [7].

Šio metodo pagrindiniai trūkumai: 1) sugaištama daug laiko atliekant kraniotomiją (ypač didelių matmenų), 2) galimos komplikacijos - subdurines ir epidurines hematomos, 3 ) pooperacinių likvorejų ar likvoro pagalvių susiformavimas, 4) galimos infekcinès žaizdos komplikacijos.

2. Endoskopinė hematomos šalinimo metodika. Pagrindinè metodo esmé: daroma frezinè anga, po to endoskopo pagalba prieinama bei matomumo ribose pašalinama hematoma. Po to atliekama hemostazè endoskopo pagalba.

Kai kurie autoriai netgi nurodo geresnius neurologinius rezultatus palyginus su atvira kraniotomija ar steriotaksiniu metodu atliekant tyrimus mažoms grupelèms, bet visgi dar labai trūksta tyrimų atsitiktinès atrankos grupėms [7,24-26].

Šio metodo pagrindiniai trūkumai: 1) negalima apžiūrèti visos hematomos ertmès dèl optikos kampų ribotumo, 2) nepakankama kraujavimo kontrolè, 3) nepilnas hematomos pašalinimas, t.y. išliekant daliai hematomos lieka ir jos ịrimo produktų, dèl to išlieka jų sukeliamos fiziologinès ir biocheminès reakcijos.

3. Stereotaksinis hematomos šalinimas su vietine fibrinolize. Naudojant įvairias navigacines sistemas i hematomos centrą įkišama kaniule ir pašalinama dalis hematomos. Po to icstumiamas ventrikulostominis kateteris ir atlikus kontrolinę KT (kompiuterinę tomografiją) pagal metodikas suleidžiamas trombolitikas. Po 1 valandos kateteris atidaromas, hematoma drenuojama. Dažniausiai kateteris paliekamas kelioms dienoms, kad galima būtų pašalinti hematomos likučius.

Šis metodas nesėkmingai nutraukiamas tuo atveju, jeigu: 1) hematoma nepašalinta suleidus iki 12 trombolitiko dozių, 2) būna pakraujavimas, infekcija ar mirtis [27,28]. Nors kai kurie autoriai rodo labai gerus šio metodo rezultatus palyginus su kitais gydymo metodais [29], tačiau dauguma autorių sutinka, kad šis metodas turi daug trūkumų [25,29].

Šio metodo pagrindiniai trūkumai: 1) negalima apžiū- 
rèti hematomos ertmès, 2) prasta kraujavimo kontrolè, 3) didesnè pakartotinių kraujavimų rizika ,4) trombolizinių preparatų (urokinazès, streptokinazès, rekombinantinis audinių plazminogeno aktyvatoriaus) brangumas, 5) paliekant kateterị kelioms dienoms hematomoje išlieka infekcijos tikimybè, 6) nepilnas hematomos pašalinimas (dažniausiai iki $80 \%$ tūrio), t.y. išliekant daliai hematomos lieka ir jos produktų įrimas, dèl ko išlieka jų sukeliamos fiziologinès ir biocheminès reakcijos, 7) nesèkmingo pašalinimo metu kartais tenka pereiti prie atviros kraniotomijos, o tai ,savo ruožtu, padidina tiek lovadienius, tiek gydymo kaštus, tiek komplikacijų skaičių.

Kadangi aukščiau aptarti chirurginiai gydymo metodai turi tiek savo stipriąsias puses, tiek nemažai trūkumų, iškilo naujos metodikos būtinybè, kuri būtų mažiau traumuojanti, nesukeltų daug komplikacijų bei būtų greitai atliekama.

Atsižvelgiant ị tai, KUL Neurochirurgijos klinikoje nuo $2007 \mathrm{~m}$ ir buvo pradèta taikyti bei sèkmingai iki šiol taikoma mažos trepanacijos (minitrepanacijos) metodika.

Šio metodo tikslas - sumažinti operacinį laiką ir sumažinti papildomą smegenų audinio žalą, tuo pačiu turèti pakankamą prièjimą prie hematomos hemostazei atlikti. Dèl to atliekama nedidelè kraniotomija ir minimali kortikotomija. Vertinant 10 metų rezultatus galima konstatuoti, kad šiuo metodu pasiekiama visos arba beveik visos hematomos evakuacija visais atvejais, pooperacinių komplikacijų skaičius palyginus su tradicine kraniotomija ženkliai mažesnis.

\section{Išvada}

Intracerebrinis kraujavimas ( $\mathrm{ICH})$ yra dažna liga, dèl kurios mirtingumas ir invalidumas yra didelis. Nors chirurginè hemoraginių insultų technika daug pažengè ị priekị, pacientų, sergančių ICH, gydymo prognozės išlieka prastos.

Šiuo metu bene dažniausiai taikomi chirurginiai gydymo metodai turi tiek savo stipriąsias puses, tiek nemažai trūkumų. Naujas mažos trepanacijos (minitrepanacijos) metodas bando sujungti jau žinomų ir plačiai naudojamų chirurginių gydymo metodų stipriąsias puses, ir yra mažiau traumuojantis, nesukeliantis daug komplikacijų bei greitai atliekamas.

Mažos trepanacijos (minitrepanacijos) metodas tinkamas intarcerebrinių hematomų šalinimo metodas. Šiuo metodu pasiekiama visos arba beveik visos hematomos evakuacija visais atvejais. Taikant ši metodą 10 metų nebuvo nei vienos tokios pooperacinès komplikacijos kaip epidurinès hematomos, subdurines hematomos bei likvorèjos. Intracerebriniu pooperacinių pakraujavimų kiekis nesiskiria nuo statistikos, šalinant hematomas kitais būdais. Todèl manau, kad šis metodas turètų būti plačiau naudojamas klinikinèje praktikoje. Literatūra

1. Kirkman MA, Mahattanakul W, Gregson BA, Mendelow AD.
The effect of the result of the STICH trial on the management of spontaneous supratentorial intracerebral haemorrhage in Newcastle. Br J Neurosurg 2008; 22(6): 739-46.

https://doi.org/10.1080/02688690802346091

2. Aghi M, Ogilvy CS \& Carter BS. Surgical management of intracerebral hemorrhge. In HH Schmidek \& DW Roberts (eds), Operative neurosurgical techniques: indications, methods, results, 5th edn, Saunden Elsevier, Edinburg, 2006; 1062-1074.

3. Qureshi AI, Mendelow AD, Hanley DF: Intracerebral haemorrhage. Lancet 2009; 373:1632-1644, https://doi.org/10.1016/S0140-6736(09)60371-8

4. Mendelow AD, Gregson BA, Fernandez HM, Murray GD, Teasdale GM, Hope DT, et al: Early surgery versus initial conservative treatment in patients with spontaneous supratentorial intracerebral haematomas in the International Surgical Trial in Intracerebral Haemorrhage (STICH): a randomised trial. Lancet 2005; 365:387-397. https://doi.org/10.1016/S0140-6736(05)70233-6

5. Andaluz N and Zuccarello M. Recent trends in the treatment of spontaneous intracerebral hemorrhage: analysis of a nationwide inpatient database. J Neurosurg 2009; 110:403-410. https://doi.org/10.3171/2008.5.17559

6. Brouwers HB, Goldstein JN. Therapeutic strategies in acute intracerebral hemorrhage. Neurotherapeutics 2012; 9(1): 87-98. https://doi.org/10.1007/s13311-011-0091-8

7. R. Reichart and S. Frank. Intracerebral hemorrhage, indication for surgical treatment and surgical techniques. The Open Critical Care Medicine Journal 2011; 4: 68-71. https://doi.org/10.2174/1874828701104010068

8. Quereshi Al, Tuhrim S, Broderick JP, Batjer HH, Hondo H,Hanley DF. Spontane ous intracerebral hemorrhage. N Engl J Med 2001; 344: 1450-60.

9. Elijovich L, Pratik VP, Hemphill JC. Intracerebral hemorrhage. Semin Neurol 2008; 28: 657-67. https://doi.org/10.1055/s-0028-1105974

10. Fujii Y, Takeuchi S, Sasaki O, Minakawa T, Tanaka R. Multivariate analysis of predictors of hematoma enlargement in spontaneous intracerebral hemorrhage. Stroke 1998; 29: 1160-6. https://doi.org/10.1161/01.STR.29.6.1160

11. Sun W, Pan W, Kranz PG, Hailey CE, Sun W. et al. Predictors of late neurological deterioration after spontaneous intracerebral hemorrhage. Neurocrit Care 2013; 19(3): 299-305. https://doi.org/10.1007/s12028-013-9894-2

12. Willie JT, Gross RE. Beyond therapeutic nihilism? The neurosurgical treatment of intracerebral hemorrhage. World Neurosurg 2013; 80(5): e135-7. https://doi.org/10.1016/j.wneu.2012.01.029

13. Hallevi H, Albright KC, Aronowski J, Barreto AD, MartinSchild S, Khaja AM. et al. Intraventricular hemorrhage: an atomic relation ships and clinical implications. Neurology 2008; 70: 848-52. 
https://doi.org/10.1212/01.wnl.0000304930.47751.75

14. Tuhrim S, Horowitz DR, Sacher M, Godbold JH. Volume of ventricular blood is an important determinant of outcome in supratentorial intracerebral hemorrhage. Crit Care Med 1999; 27(3): 617-21.

https://doi.org/10.1097/00003246-199903000-00045

15. Hanley DF: Intraventricular hemorrhage: severity factor and treatment target in spontaneous intracerebral hemorrhage. Stroke 2009; 40:1533-1538. https://doi.org/10.1161/STROKEAHA.108.535419

16. Nyquist $P$, Hanley DF: The use of intraventricular thrombolytics in intraventricular hemorrhage. J Neurol Sci 2007; 261:84-88. https://doi.org/10.1016/j.jns.2007.04.039

17. Naff NJ. Intraventricular hemorrhage in adults. Curr Treat Op tions Neurol 1999; 1(3): 173-8. https://doi.org/10.1007/s11940-999-0001-0

18. Brott T, Broderick J, Kothari R, Barsan W, Tomsick T, Sauerbeck L. et al: Early hemorrhage growth in patients with intracerebral hemorrhage. Stroke 1997; 28:1-5. https://doi.org/10.1161/01.STR.28.1.1

19. Xi G, Keep RF, Hoff JT: Mechanisms of brain injury after intracerebral hemorrhage. Lancet Neurol 2006; 5:53-63. https://doi.org/10.1016/S1474-4422(05)70283-0

20. Wagner KR, Xi G, Hua Y, Zuccarello M, de Courten-Myers GM, Broderick JP. et al: Ultra-early clot aspiration after lysis with tissue plasminogen activator in a porcine model of intracerebral hemorrhage: edema reduction and blood-brain barrier protection. J Neurosurg 1999; 90:491-498.

https://doi.org/10.3171/jns.1999.90.3.0491

21.Dey M, Stadnik A, Awad IA. Thrombolytic evacuation of intracerebral and intraventricular hem or rhage. Curr Cardiol Rep 2012; 14(6): 754-60. https://doi.org/10.1007/s11886-012-0316-4

22. Zhou X, Chen J, Li Q, Ren G, Yao G, Liu M, et al. Minimally invasive surgery for spontaneous supratentorial intracerebral hemorrhage: a meta-analysis of randomized controlled trials. Stroke 2012; 43(11): 2923-30. https://doi.org/10.1161/STROKEAHA.112.667535

23. Morgenstern LB, Hemphill JC, An der son C, Becker K, Broderick JP, Connoly ES, et al. Guide lines for the management of spontaneous intracerebral hemorrhage: a guideline for healthcare pro fessionals from the American Heart Association/ American Stroke Association. Stroke 2010; 41: 2108-29. https://doi.org/10.1161/STR.0b013e3181ec611b
24. Auer LM, Holzer P, Ascher PW, Heppner F. Endoscopic neurosurgery. Acta Neurochir (Wien) 1988; 90(1-2): 1-14.

https://doi.org/10.1007/BF01541260

25. Nishihara T, Morita A, Teraoka A, Kirino TK. Endoscopyguided removal of spontaneous intracerebral hemorrhage: comparison with computer tomography-guided stereotactic evacuation. Childs Nerv Syst 2007; 23: 677-83. https://doi.org/10.1007/s00381-007-0325-6

26. Cho D, Chen C, Chang C, Lee W, Tso M. Endoscopic surgery for spontaneous basal ganglia hemorrhage: comparing endoscopic surgery, stereotactic aspiration, and craniotomy in noncomatouse patients. Surg Neurol 2006; 65: 547-56.

https://doi.org/10.1016/j.surneu.2005.09.032

27. Naff N, Wil liams MA, Keyl PM, Tuhrim S, Bull ock MR,Mayer $\mathrm{SA}$, et al. Low-dose recombinant tissue-type plasminogen activator enhances clot resolution in brain hemorrhage: the intraventricular hemorrhage thrombolysis trial. Stroke 2011; 42(11): 3009-16. https://doi.org/10.1161/STROKEAHA.110.610949

28. Ziai WC, Tuhrim S, Lane K, McBee N, Lees K, Dawson J, et al. A multicenter, randomized, double-blinded, placebo-controlled phase III study of Clot Lysis Evaluation of Accelerated Resolution of Intraventricular Hemorrhage (CLEAR III). Int J Stroke 2013 Aug 28.

29. Simaitis K., Bernotas G. Minimaliai invazinis intracerebrinių ir intraventrikulinių kraujosruvų gydymas, taikant vietinę fibrinolizę. Neurologijos seminarai, 2014; 18(60): 98-104.

\section{SMALL TREPANATION (MINI-TREPANATION) METHOD BY REMOVING THE BRAIN HEMORRHAGIC STROKE. THE CLINICAL CASE AND A DESCRIPTION OF THE METHODOLOGY}

\section{Aleksandrov}

Key words: intracerebral bleeding, pathophysiology of intracerebral hematoma, removal methods of intracerebral hematomas, small trepanation (Mini-trepanation) method.

Summary

This article is dedicated to analize surgical methods of intracerebral hematomas, main advantages and disadvantages of these methods. Moreover, clinical case and methodical recommendation of removing intracerebral hematomas, using new method-small trapanation and Mini-trepenation are analized too.

Correspodence to: dr.aleksandrov@gmail.com

Gauta 2017-11-06 